\title{
Pemberdayaan Perempuan Melalui Program UP2K untuk Meningkatkan Kesejahteraan Keluarga di Desa Bunga Tanjung Kabupaten Kerinci
}

\section{Fadilla Ulpa, Fatmariza}

Prodi Pendidikan Pancasila dan Kewarganegaraan

FIS Universitas Negeri Padang

E-mail: Fadillaulpa25@gmail.com

\section{ABSTRAK}

Artikel ini bertujuan untuk menganalisis pelaksanaan pemberdayaan perempuan melalui Program UP2K Usaha Setia di Desa Bunga Tanjung Kabupaten Kerinci. Jenis penelitian ini adalah penelitian kualitatif dengan menggunakan metode Deskriptif. Informan ditentukan secara purposive sampling, data dikumpulkan melalui observasi, wawancara dan dokumentasi. Uji keabsahan data dilakukan melalui Triangulasi sumber dan motode. Teknik analisis data menggunakan tahap reduksi data, penyajian data, dan penarikan kesimpulan. Hasil penelitian menunjukkan bahwa dengan adanya program UP2K Usaha Setia telah membantu meningkatkan kesejahteraan keluarga melalui program-program yang bernilai ekonomis. Ada beberapa bentuk pemberdayaan yang dilakukan yaitu: pelaksanaan pembuatan anyaman bambu, kegiatan simpan pinjam up $2 k$ usaha setia, dan pemberdayaan sosial perempuan. Akan tetapi masih ada kendala dalam pemberdayaan ini karena partisipasi perempuan masih rendah. Rendahnya partisipasi ini disebabkan oleh beberapa hal seperti kurangnya sosialisai, pelatihan dari pemeritah dan rendahnya pendidikan bagi perempuan.

Kata Kunci: pemberdayaan, pemberdayaan perempuan, program UP2K

\section{ABSTRACT}

This article aims to analyze the implementation of women's empowerment through the UP2K Usaha Setia Program in Bunga Tanjung Village, Kerinci Regency. This type of research is qualitative research using descriptive methods. The informants were determined by purposive sampling, the data were collected through observation, interviews and documentation. The data validity test was carried out by means of triangulation of sources and methods. The data analysis technique uses the stage of data reduction, data presentation, and drawing conclusions. The results showed that the UP2K Usaha Setia program has helped improve family welfare through programs with economic value. There are several forms of empowerment, namely; Implementation of Bamboo Matting, UP2K Savings and Loan Activities for Faithful Business, Women's Social Empowerment. However, there are still obstacles in this empowerment because women's participation is still low. This low participation is caused by several things such as lack of socialization, training from the government and low education for women. 
Keywords: empowerment, women empowerment, UP2K

This work is licensed under the Creative Commons Attribution-ShareAlike 4.0 International License. (C)2020 by author.

\section{PENDAHULUAN}

Pentingnya pemberdayaan perempuan terutama pada keluarga miskin perlu adanya kegiatan aksi nyata dalam bidang sosial ekonomi. Salah satu cara untuk memberdayakan semua lapisan masyarakat di antaranya melalui tindakan pemberdayaan perempuan. Menurut Tiara (2018) Pemberdayaan perempuan adalah proses yang dilakukan untuk menambah kemampuan yang dimiliki perempuan dalam mendapatkan akses dan kontrol terhadap sumber daya dalam semua aspek kehidupan. Sedangkan menurut Syarif (2018), program pemberdayaan dapat meningkatkan peran perempuan di dalam bidang ekonomi salah satunya yaitu ikut berperan dalam membuat program-program yang merujuk pada pemberdayaan perempuan dengan meluncurkan Program UP2K. Program ini berupaya untuk menciptakan usaha-usaha bagi perempuan dalam mengembangkan keterampilan.

$$
\text { Upaya Peningkatan }
$$

Pendapatan Keluarga atau UP2K adalah program untuk mengatasi masalah kemiskinan khususnya bagi perempuan. Program ini dibuat untuk mengembangkan kegiatan usaha bagi perempuan yang tergabung di dalam program tersebut, sehingga diharapkan perempuan mampu menciptakan keluarga yang sejahtera, Indarto (2019). Kegiatan ini sesuai dengan amanat Undang-Undang No 23 Tahun 2014, tentang Pemerintah Daerah, yang mengatakan bahwa penyelenggaraan pemerintahan daerah diarahkan untuk mempercepat terwujudnya kesejahteraan masyarakat melalui peningkatan pelayanan, pemberdayaan, dan peran serta masyarakat, serta meningkatkan daya saing daerah dengan memperhatikan prinsip demokrasi, pemerataan, keadilan, dan kekhasan suatu daerah dalam bingkai NKRI.

Beberapa penelitian terdahulu menunjukkan bahwa pemberdayaan perempuan melalui Program UP2K dapat membantu meningkatkan perekonomian dan kesejahteraan anggota keluarga. Peneliatian yang pernah dilakukan oleh Nurfadillah (2019) menunjukkan bahwa untuk memberdayakan perempuan melalui kelompok Program UP2K Rumah Sumpia yaitu dengan kegiatan mengolah makanan menjadi kerupuk ikan untuk dijual. Hasil yang didapatkan telah meningkatkan perekonomian, sehingga dapat terbantu kesejahteraan keluarga. Selanjutnya penelitian yang dilakukan oleh Maryati (2017) menunjukkan bahwa memberdayakan perempuan melalui Program UP2K dengan bentuk usaha yaitu menciptakan berbagai kreasi makanan dari bahan baku sagu menjadi kue untuk dijualkan agar perempuan mendapatkan penghasilan supaya membantu meningkatkan kesejahteraan keluarga. 
Sedangkan penelitian yang dilakukan oleh Handayani (2019) menunjukkan bahwa pemberdayaan perempuan melalui Program UP2K dengan kegiatan Mitra yang merupakan kelompok ibu rumah tangga yang menghasilkan aneka camilan bakso untuk dijualkan dengan modal yang terbatas sehingga dari hasil tersebut dapat terbantu kebutuhan keluarga. Selanjutnya penelitian yang dilakukan Indarto (2019) menunjukkan bahwa pemerdayaan perempuan melalui Program UP2K dengan kegiatan mengembangkan produk detergent matic, yaitu detergent untuk mesin cuci. Kelompok tersebut sangat memerlukan pengabdian, dimana bisnis usaha ini belum berjalan secara maksimal, sehingga hanya dapat membantu kebutuhan dan belum dikatakan sejahtera. Perbedaan dan persamaan pada penelitian ini memiliki perbedaan pada objek, subjek dan fokus penelitian dengan peneliti sebelumnya. Adapun objek dalam penelitian ini yaitu mengolah anyaman bambu menjadi sebuah produk sehingga bernilai jual untuk memabantu perekonomian keluarga.

Berdasarkan observasi awal yang didapatkan Desa Bunga Tanjung merupakan desa yang aktif melaksanakan pemberdayaan perempuan melalui Program UP2K yang dinamakan kelompok Usaha Setia. Perempuan di desa tersebut lebih dominan pendapatan ekonomi hanya bergantung pada suami tentu tidak cukup untuk memenuhi kebutuhan, sedangkan jumlah penduduk perempuan 577 orang $(53,47 \%)$, lebih tinggi dibadingkan laki-laki yaitu sebanyak 502 orang $(46,52 \%)$ sehingga total populasi penduduk sebanyak 1079 orang, dan terlihat banyaknya potensi yang dimiliki perempuan untuk dapat dikembangkan, namun masih banyak jumlah kepala keluarga yang berada pada tingkat pra sejahtera sebanyak 203 KK $(65,3 \%)$ kemudian jumlah kepala keluarga sejahtera sebanyak 108 KK $(34,7 \%)$, jadi total kepala keluarga di Desa Bunga Tanjung Kabupaten Kerinci sebanyak 311 KK.

Program UP2K Usaha Setia bermanfaat bagi usaha kaum perempuan, dimana perempuan disana cukup banyak yang berada pada tingkat prasejahtera yang berprofesi sebagai ibu rumah tangga. Namun pada kenyataannya, perempuan disana masih kurang untuk berpartisipasi dalam mengikuti kegiatan program ini. Kurangnya partisipasi disebabkan karena kurangnya pelatihan, sosialisasi dan pembinaan dari pemerintah maupun dari pengelola kelompok, sehingga membuat program tersebut cenderung pasif. Selanjutnya, hasil manajemen pemasaran produk usaha belum maksimal dalam meningkatkan kesejahteraan keluarga, dan juga tingkat pendidikan perempuan disana masih rendah yang membuat pengetahuan yang dimiliki perempuan sedikit dalam membuat usaha. Selain itu, minimnya kualitas SDM yang berdampak pada sulitnya untuk melakukan inovasi pada produk.

Adapun kegiatan didalam Program UP2K Usaha Setia yang dilakukan perempuan yaitu mengolah anyaman bambu menjadi sebuah produk yang bernilai jual untuk dipasarakan seperti topi sawah, gantungan kuci, bakul beras, keranjang buah-buahan, tas, tempat 
minuman kemasan, dan sebagainya tergantung produk apa yang diinginkan pembeli. Membuat anyaman bambu melalui beberapa proses yaitu salah satu tahapannya dipotong menjadi bagian kecil untuk dianyaman menjadi produk, sehingga produk yang dijual akan mendapatkan hasil yang didapatkan untuk membantu meningkatkan kesejahteraan keluarga dengan memiliki pendapatan sendiri. Anyaman bambu ini didapatkan dengam memanfaatkan sumber daya lokal yang dimiliki yaitu bambu, di Desa Bunga tanjung memiliki perkebunan bambu yang luasnya sekitar $1 / 2$ Ha yang mendorong mereka untuk mengolah bambu yang didapatkan dari perkebunanan bambu.

Berdasarkan latar belakang dan hasil penelitian sebelumnya mengenai Program UP2K, dapat di buktikan dengan adanya Program UP2K, perempuan dapat membantu memenuhi kebutuhan keluarga, tetapi masih belum dikatakan sejahteara. Tujuan dari penulisan artikel ini untuk melihat pelaksanaan pemberdayaan perempuan, kurangnya partisipasi perempuan untuk mengikuti kegiatan UP2K Usaha Setia dan manfaat ekonomi pemberdayaan perempuan sehingga penting untuk di teliti.

\section{METODE PENELITIAN}

$\begin{array}{lrr}\text { Jenis penelitian ini } & \text { adalah } \\ \text { penelitian } & \begin{array}{r}\text { kualitatif } \\ \text { dengan }\end{array} \\ \text { menggunakan } & \text { metode } & \text { Deskriptif. }\end{array}$
Penelitian kualitatif merupakan suatu penelitian ilmiah yang bertujuan untuk memahami suatu fenomena dalam konteks sosial, Herdiansyah (2010:9). Lokasi penelitian ini berada di Desa Bunga Tanjung Kabupaten
Kerinci Provinsi Jambi yang terdapat Program UP2K Usaha Setia. Lokasi ini dipilih untuk menjadikan tempat penelitian karena memfokuskan usaha dari program UP2K Usaha Setia yaitu kegiatan anyaman bambu yang diolah menjadi sebuah produk yang bernilai jual untuk meningkatkan kesejahteraan keluarga.

Informan dalam penelitian ini yaitu 1) Kepala Badan Pemberdayaan Perempuan Kabupaten Kerinci, 2) Kepala Desa Bunga Tanjung, 3) Tokoh Masyarakat Pemangku adat Desa Bunga Tanjung, 4) Ketua Pemuda Desa Bunga Tanjung, 5) Pengurus UP2K Usaha Setia, 6) Anggota UP2K Usaha Setia, 7) Suami anggota UP2K Usaha Setia, 8) Anak anggota UP2K Usaha Setia, 9) Pembeli Anyaman Bambu. Teknik pengumpulan data pada peneitian ini menggunakan metode wawancara, observasi, dan studi dokumentasi. Teknik analisis data dilakukan dari pengumpulan data, reduksi data, penyajian data, dan menarik kesimpulan atau verifikasi.

\section{HASIL DAN PEMBAHASAN}

\section{Bentuk Bentuk Kegiatan Pemberdayaan Perempuan Melalui Program UP2K Usaha Setia}

a) Pelaksanaan Pembuatan Anyaman Bambu

Proses pembuatan anyaman bambu dibuat dengan cara bambu dianyam hingga menjadi sebuah produk bernilai jual, belum berjalan secara maksimal. Karena kurangnya partisipasi dari perempuan untuk mengikuti kegiatan UP2K Usaha Setia. Kegiatan tersebut dilakukan satu kali dalam seminggu dengan jumlah anggota 41 orang. Produk yang sudah jadi akan dipromosikan melalui media 
sosial yaitu facebook dan instagram tetapi pemasaran didalam media sosial masih belum maksimal karena anggota masih belum paham dalam penggunaan internet, sehingga dalam kegiatan promosi tidak berjalan secara maksimal yang mengakibatkan pendapatan hanya dapat membantu kebutuhan keluarga.

Hal tersebut tidak sejalan dengan teori Mardikanto, Totok \& Soebianto, Poerwoko (2017:105), karena pada teori ini dijelaskan bahwa mengerjakan merupakan kegiatan pemberdayaan harus melibatkan masyarakat, sedangkan kenyataan dilapangan dalam proses pembuatan anyaman bambu melalui beberapa tahapan seperti bambu dianyaman hingga menjadi sebuah produk belum berjalan secara maksimal, yang disebabkan karena kurangnya partisipasi dari masyarakat. Namun, dalam proses pemasaran juga belum maksimal karena dalam penggunaan media sosial anggota masih pasif dan belum paham menggunakan teknologi seperti internet sehingga banyak masyarakat dari luar belum mengetahuinya, dalam proses pemasaran anyaman bambu hanya dipromosikan atau dijual pada saat acara tertentu seperti Festival Danau Kerinci. Sejalan dengan hasil penelitian terdahulu Handayani (2019) mengatakan bahwa masih kurangnya keterbatasan ilmu pengetahuan dan teknologi masyarakat untuk mempromosikan produk dengan menggunakan internet, serta belum adanya kegiatan pelatihan inovasi produk yang menuju pada kualitas produk sehingga produk belum dikenal oleh masyarakat luas.

b) Kegiatan Simpan Pinjam UP2K Usaha Setia
Dalam kegiatan Program UP2K Usaha Setia dilaksanakan kegiatan simpan pinjam yang bertujuan untuk mengajarkan ibu-ibu yang tergabung dalam kelompok usaha agar menyisihkan uang dari hasil pendapatan anyaman bambu untuk menjadikan modal usaha. Simpan pinjam ini bermanfaat bagi anggota yang membutuhkan dimana setiap anggota boleh meminjam uang simpan pinjam tergantung kesepakatan kelompok. Sehingga dapat memberikan manfaat bagi keluarga demi membantu dalam memenuhi kebutuhan keluarga.

Hal tersebut sesuai dengan teori Mardikanto, Totok \& Soebianto, Poerwoko (2017:105), karena pada teori ini dijelaskan Asosiasi merupakan kegiatan pemberdayaan harus dikaitkan dengan kegiatan lain. Sedangkan kenyataan dilapangan selain pelaksanaan anyaman bambu juga dilaksanakan kegiatan lain yaitu simpan pinjam yang berguna untuk menambah modal untuk mengembangkan usaha kelompok sehingga akan menghasilkan produk anyaman bambu yang berkualitas. Kegiatan ini sudah terlaksana dengan baik yang membuat anggota dapat membantu anggota lain bagi yang membutuhkan.

c) Pemberdayaan Sosial Perempuan

Dalam pelaksanaan kegiatan pemberdayaan perempuan juga melakukan kegiatan sosial seperti dana sosial yang berguna untuk membantu membeli kebutuhan dalam membuat anyaman bambu, dan juga digunakan bagi anggota-anggota atau keluarga yang sakit, sehingga terbentuk sikap kekeluargaan dan 
Journal of Civic Education (ISSN: 2622-237X)

Volume 3 No. 32020

kepedulian sesama anggota. Kegiatan ini sangat bermanfaat karena perempuan belajar bagaimana untuk saling berinteraksi dengan anggota lain. Hal tersebut sesuai dengan teori Mardikanto, Totok \& Soebianto, Poerwoko (2017:105), karena pada teori ini dijelaskan bahwa akibat merupakan kegiatan pemberdayaan yang memberikan manfaat, sehingga memberikan pengaruh yang baik bagi anggota untuk mengembangkan usaha kelompok dengan menggunakan dana sosial, selain itu juga memberikan manfaat bagi individu dengan terbentuknya sikap kebersamaan didalam kelompok karena dana sosial dipergunakan untuk menjenguk bagi anggota atau keluarga yang sakit. Pada kenyataan dilapangan sudah berjalan secara baik karena juga untuk membantu menambah modal usaha.

Jadi, dalam pelaksanaan
pembuatan anyaman bambu
dilakukan dengan tahapan bambu dianyam hingga menjadi sebuah produk kemudian dipromosikan melalui media sosial yaitu facebook dan Instagram. Kemudia didalam program ini memiliki kegiatan lain yaitu simpan pinjam yang bertujuan untuk menjadikan modal agar usaha dapat berkembang. Dengan adanya program ini memberikan pengaruh yang positif bagi masyarakat baik bagi individu maupun kelompok karena terbentuknya pribadi yang lebih mandiri untuk menambah kebutuhan keluarga.

\section{Faktor-Faktor Penyebab Rendahnya Partisipasi Perempuan dalam Mengikuti Kegiatan UP2K Usaha Setia}

Berdasarkan hasil penelitian ditemukan bahwa pemberdayaan perempuan melalui program UP2K Usaha Setia memiliki beberapa faktor penyebab perempuan kurang berpartisipasi dalam mengikuti kegiatan UP2K Usaha Setia yaitu.

a) Kurangnya Kesadaran Untuk Berpartisipasi

Dalam pelaksanaan kegiatan anyaman bambu melalui Program UP2K Usaha Setia, kaum perempuan lebih dominan berprofesi sebagai ibu rumah tangga, yang mengakibatkan pendapatan hanya bergantung pada suami. Meskipun terdapat beberapa perempuan yang tidak berpartisipasi dalam mengikuti kegiatan usaha. Disebabkan karena mereka tidak melihat dampak ekonomi secara langsung yang dirasakan oleh anggota UP2K, padahal memberikan manfaat ekonomi bagi perempuan. Produk anyaman bambu memiliki unsur seni di dalamnya, tentu perempuan harus memiliki bakat atau skill dalam pembuatan anyaman bambu.

Pada kenyataannya masih ada perempuan yang tidak memiliki bakat atau seni dalam membuat anyaman bambu sehingga mereka tidak tertarik dalam mengikuti kegiatan UP2K sehingga inovasi-inovasi baru dari pemerintah maupun masyarakat lainnya. Selanjutnya kurangnya pelatihan dari pengelola anyaman bambu karena dalam membuat anyaman bambu perlu ketelitian agar menjadikan produk yang berkualitas, ditambah lagi kurangnya dorongan motivasi dari pemerintah maupun masyarakat yang membuat mereka tidak membutuhkan pendapatan ekonomi. Pemerintah hanya memberikan modal kepada kelompok usaha apabila ada perlombaan atau acara-acara penting di kabupaten. 
Kemudian kurangnya pelatihan yang diberikan kepada masyarakat sehingga perempuan disana tidak tertarik dan tidak memiliki pengetahuan dalam mengembangkan keterampilan untuk membuat anyaman bambu, sehingga perempuan disana kurang aktif dalam mengikuti kegiatan kelompok usaha.

Hal tersebut tidak sesuai dengan teori Mulyana (2017) mengatakan indikator pemberdayaan adalah kemampuan orang, khususnya kelompok rentan dan lemah untuk mempunyai akses terhadap sumbersumber produktif yang dapat meningkatkan kesejahteraannya dan berpatisipasi dalam proses pengambilan keputusan yang dapat mempengaruhi mereka. dalam indikator pemberdayaan pada kenyataannya, teori akses sejalan dengan kenyataan dilapangan. Program UP2K Usaha Setia merupakan akses perempuan untuk bekerja demi membantu kebutuhan keluarga, sudah berjalan secara maksimal, dimana perempuan menghasilkan produk anyaman bambu yang berkualitas.

Teori partisipasi tidak sejalan dengan kenyataan dilapangan perempuan disana kurang berpartisipasi dalam mengikuti kegiatan Program UP2K Usaha Setia disebabkan karena tingkat pendidikan yang masih rendah. Kemudian, kurangnya sosialisasi dari pemerintah maupun kelompok untuk memberikan pelatihan bagi perempuan, karena dalam proses pembuatan anyaman bambu kesadaran perempuan disana lebih dominan. Ditambah lagi membutuhkan bakat seni dan skill. Sehingga membuat perempuan disana kurang memiliki kesadaran dalam berartisipasi untuk mengikuti kegiatan Program UP2K Usaha Setia.

b) Beban Ganda Perempuan Kerajinan Anyaman Bambu

Berdasarkan hasil penelitian yang didapatkan perempuan disana memiliki beban ganda, dimana harus mengurus rumah tangga dan bekerja, perempuan tersebut harus bisa membagi antara mengurus rumah tangga yaitu mengurus anak, mengurus suami, mengerjakan pekerjaan rumah seperti menyapu, mencuci baju, mencuci piring dan bekerja sampingan, karena perempuan tidak harus bergantung pada suami, dan menjadikan perempuan lebih mandiri. Namun, masih ada suami yang tidak memberi izin perempuan untuk mengikuti kegiatan usaha dikarenakan harus mengurus rumah tangga. Itulah yang menjadi penyebab perempuan kurang berpartisipasi dalam mengikuti kegiatan kelompok UP2K Usaha Setia.

Namun berbeda dengan kenyataan dilapangan menuru Yeselin (2017) mengatakan untuk meningkatkan kualitas hidup atau kesejahteraan bagi kaum perempuan dapat dilakukan dengan cara memberikan keadilan yang setara antara kaum laki-laki dengan kaum perempuan. Serta memberikan kesempatan bagi kaum perempuan untuk turut serta dalam mengambil keputusan. Pada kenyataan dilapangan masih ada perempuan yang tidak mau bekerja disebabkan karena kedudukan perempuan memiliki beban ganda antara mengurus rumah tangga dan bekerja, tentu tidah mudah membagikan waktu dan memilih mengikuti kata suami. 
Journal of Civic Education (ISSN: 2622-237X)

Volume 3 No. 32020

\section{c) Rendahnya Pendapatan Masayarakat}

Berdasarkan hasil penelitian yang dilakukan, pendapatan yang didapat masyarakat masih tergolong rendah dan tidak ada peningkatan yang signifikan. Kemudian kurangnya perhatian dari pemerintah mengenai kesejahteraan masayarakat mengakibatkan rendahnya pendapatan masyarakat terutama dalam keluarga. Pada kenyataannya sebagian masyarakat masih ada yang menganggap kurang cukup untuk memenuhi kebutuhan keluarga, karena perempuan kurang menekuni dalam membuat kerajinan anyaman bambu, namun dengan hasil tersebut dapat terbantu untuk menambah penghasilan keluarga.

$\begin{array}{cccc}\text { Sama } & \text { hal dengan hasil } \\ \text { penelitian } & \text { oleh Indarto } & \text { (2019) }\end{array}$ menunjukkan bahwa dalam usaha UP2K dengan kegiatan berbeda yaitu mengembangkan produk detergent matic, yaitu detergen untuk mesin cuci yang dikelola tidak terencana dengan baik. Kondissi ini mengakibatkan rendahnya pendapatan yang didapatkan dari hasil kegiatan UP2K. Pada kenyataan dilapangan kurangnya perhatian dari pemerintah yang menyebabkan kelompok usaha belum berhasil sehingga perlu pelatihan secara mendalam.

Jadi, kurangnya partisipasi perempuan disebabkan karena tingkat pendidikan perempuan yang masih tergolong rendah ditambah lagi kurangnya sosialisasi dan pelatihan dari pemerintah yang membuat kaum perempuan kurang aktif untuk mengikuti kegiatan usaha. Sedangkan, perempuan memiliki beban ganda seperti mengurus rumah tangga dan bekerja. Kedudukan perempuan itulah yang menjadi penyebab pendapatan yang didapatkan dari hasil usaha tergantung perempuan dalam menekuninya karena harus bisa membagi waktu antara mengurus rumah tangga dan bekerja.

\section{Manfaat Program UP2K Usaha Setia Bagi Perempuan dan Keluarga}

Berdasarkan hasil penelitian, ditemukan bahwa pemberdayaan perempuan melalui program UP2K Usaha Setia di Desa Bunga Tanjung Kerinci memberikan manfaat yang baik bagi anggota kelompok dalam mengembangkan usaha, manfaat yang didapatkan dari program ini yaitu:

a) Meningkatkan Kesejahteraan Keluarga

Berdasarkan hasil penelitian yang didapatkan Program UP2K Usaha Setia menjadi wadah bagi perempuan disana untuk dapat mengembangkan keterampilan dalam membuat anyaman bambu. Kemudian menjadikan sebuah produk yang bernilai jual yang akan membuat usaha kelompok menjadi berkembang. Adanya program ini memberikan manfaat ekonomi bagi perempuan sehingga dapat terbantu kebutuhan keluarga dalam meningkatkan kesejahteraan keluarga seperti kebutuhan sandang pangan dan papan yang menjadikan perempuan disana lebih mandiri.

Sejalan dengan penelitian
terdahulu Handayani
mengatakan didalam program UP2K
dilakukan usaha membuat kue
cemilan yang hanya mampu
meningkatkan kesejahteraan keluarga.
Hal ini disebabkan karena kurangnya
pemasaran yang dilakukan


pemerintah. Namun pada kenyataan dilapangan pada penelitian ini, dalam pembuatan anyaman bambu melalui program UP2K perlu adanya perhatian dari pemerintah maupun kelompok baik dari segi pemasaran, pelatihan dan mensosialisasikan kepada masyarakat.

b) Menambah Pengetahuan dan Sosial Masyarakat

Pelaksanaan program UP2K Usaha Setia dapat menambah pengetahuan dan sosial masyarakat seperti menumbuhkan rasa kebersamaan didalam kelompok usaha, juga menambah pengetahuan dengan membuat produk dengan kreasi baru, seperti dalam membuat motif yang mudah hingga sulit yang dibuat oleh kelompok usaha perempuan. Dalam usaha ini juga memberi manfaat sebagai tambahan wawasan dan pengetahuan untuk mengembangkan keterampilan dalam membuat anyaman bambu. Dengan demikian timbul lah rasa kekeluargaan dan kepedulian terhadap anggota maupun masyarakat.

Sejalan dengan teori Nurfadillah (2019) mengatakan dalam mengembangkan usaha mempunyai tujuan utama yaitu untuk meningkatkan kemampuan dan keterampilan masyarakat yang berpendapatan rendah, memberikan kesempatan kepada pengusaha kecil untuk mengembangkan modal usahanya, sehingga dapat menjadikan perempuan yang mandiri. sedangkan pada kenyataan dilapangan perempuan disana mampu mengolah sumber daya yang ada dengan membuat produk yang berkualitas. Dengan adanya program tersebut memberikan mereka kesempatan untuk mengembangkan keterampilan mereka dengan mendapatkan pengetahuan baru sehingga timbullah jiwa sosial masyarakat didalam anggota kelompok usaha.

c) Meningkatkan Inovasi dan Kemandirian Perempuan

Program UP2K Usaha Setia membantu perempuan untuk lebih mandiri dan menumbuhkan inovasi pada diri perempuan dalam membuat ide-ide baru. Sebelumnya perempuan hanya bisa membuat beberapa produk seperti tempat minuman kemasan, tempat piring. Namun, sekarang perempuan bisa berkreasi dengan belajar menciptakan produk baru lebih banyak lagi. Dengan adanya anggota muda yang tergabung dapat memberikan inovasi baru untuk anggota lainnya, sehingga dapat meneruskan generasi muda agar anyaman bambu tidak hilang dengan perkembangan zaman.

$\begin{array}{llr}\text { Sejalan } & \text { dengan } & \text { penelitian } \\ \text { terdahulu } & \text { Yeselin } & \text { (2017) }\end{array}$
Pemberdayaan perempuan juga mengedepankan masalah kemandirian kaum perempuan agar tidak terlalu bergantung kepada orang lain. Potensi dan kemampuan yang dimiliki dapat diterapkan secara maksimal. Kemandirian yang sejati memberikan kekuatan untuk melakukan kemandirian berfikir dalam menentukan sikap. Sedangkan kenyataan dilapangan anggota kelompok saling bekerja sama untuk menciptakan ide-ide produk baru sehingga hasil yang didapatkan memberi manfaat bagi perempuan untuk menjadi lebih mandiri dan tidak bergantung pada suami. Selain itu dengan adanya program UP2K 
membantu perempuan menjadi lebih mandiri dan dapat diberdayakan.

Dengan demikian, Program UP2K Usaha setia memberi manfaat ekonomi bagi perempuan disana melalui kelompok usaha menjadi tempat perempuan untuk mengembangkan keterampilannya, sehingga perempuan dapat memiliki pengetahuan dan kemandirian dengan cara berinteraksi dengan anggota lain untuk saling bekerja sama. Dengan adanya anggota yang berkualitas mampu mencari ide-ide dalam menciptakan inovasi baru untuk menjadikan perempuan yang mandiri.

\section{KESIMPULAN}

Berdasarkan hasil penelitian dan pembahasan dapat disimpulkan bahwa pelaksanaan program UP2K Usaha setia belum berjalan secara maksimal disebabkan karena kurangnya partisipasi dari perempuan. Ditambah lagi permasalahan seperti belum maksimalnya pemasaran produk disebabkan karena perempuan belum paham dalam penggunaan internet, sehingga banyak yang tidak mengetahui produk anyaman bambu. Dengan adanya program ini telah membantu meningkatkan kesejahteraan keluarga, tetapi masih terjadi permasalahan yaitu kurangnya sosialisasi dan pelatihan dari pemerintah maupun kelompok yang membuat kurangnya minat perempuan dalam partisipasi untuk mengikuti kegiatan UP2K Usaha setia.

Dalam indikator pemberdayaan sudah sampai pada tingkat akses karena pada tingkat kesejahteraan anggota kelompok masih belum maksimal dalam mengembangkan usaha anyaman bambu, sehingga hanya dapat membantu meningkatkan kesejahteraan keluarga. Kegiatan ini tidak hanya memberi manfaat ekonomi saja tetapi juga memberi manfaat bagi individu dan kelompok untuk dapat bekerja sama dalam mengembangkan usaha. Pada gilirannya timbullah sikap kebersamaan didalam kelompok maupun masyarakat.

Diharapkan kepada pemerintah di Desa Bunga Tanjung Kabupaten Kerinci agar selalu memberikan sosialisasi kepada masyarakat terutama perempuan untuk mengikuti kegiatan Program UP2K Usaha Setia dan juga memberikan pelatihan yang lebih agar perempuan disana dapat mengembangkan keterampilannya. Tidak hanya itu pemerintah juga harus mempromosikan anyaman bambu dengan selalu mengikutsertakan kelompok Program UP2K Usaha Setia dalam mengikuti pameran dan perlombaan. Sehingga anyaman bambu ini dapat dikenal oleh masyarakat luas.

\section{DAFTAR PUSTAKA}

Mardikanto, Totok \& Soebianto, Poerwoko. 2017. Pemberdayaan Masyarakat Dalam Perspektif Kebijakan Publik. Bandung: Alfabeta

Herdiansyah, Haris. 2014. Metodologi Penelitian Kualitatif. Jakarta Selatan: Salemba Humanika.

Nurfadillah, Siti Utami. 2019. Meningkatkan Kesejahteraan Masyarakat Melalui Program Up2k-Pkk Di Desa Kayuambon Lembang. Jurnal CommEdu.Vol 2, No 1. e-ISSN : 26151480 p-ISSN: 2622-5492. 
Maryati, Rusli Zaili. 2017. Pelaksanaan Program Upaya Peningkatan Pendapatan Keluarga (Up2k) Di Desa Sungai Tohor Kec.Tebingtinggi Timur Kabupaten Kepulauan Meranti. Jurnal JOM FISIP Vol. 4 No 1.

Indarto. 2019. Peningkatan Kinerja Usaha Mikro Melalui Penyusunan Rencana Usaha Dan Laporan Keuangan Pada Kelompok Up2k Kelurahan Gisikdrono, Kecamatan Semarang Barat. Journal of Social Dedication. Vol. 2, Nomor 2. e-ISSN: 2599-1000 ISSN: 2599-0713.

Handayani, Susi. 2019. Program Kemitraan Masyarakat Upaya Peningkatan Pendapatan Keluarga (UP2K) Kelurahan Mabar Kecamatan Medan Deli. Jurnal Seminar Nasional Kewirausahaan. Vol 1 No 1. ISSN 2714-8785

Syarif, Asriyanti. 2018. Kajian Persfektif Gender Perempuan Tani Dari Sudut Ekonomi Pada Usahatani Rumput Laut Di Kabupaten Bulukumba. Jurnal Ziraa'ah. Vo 43. No 3. E-Issn 2355-3545

Bachtiar, Y. (2018). Pemberdayaan Perempuan melalui Kelompok Pengrajin Sulaman Bayangan di Barung-Barung Belantai Kabupaten Pesisir Selatan. Journal of Civic Education, 1(3), 280-288.

Mulyana, Nandang. 2017. Pemberdayaan Perempuan Melalui Program Keluarga Berencana. Jurnal Prosiding Ks: Riset \& Pkm. Vol 4 No 1.

Yeselin, Icha Maria. 2017. Negara Dan Pemberdayaan Perempuan
(Studi: Upaya Bppmkb Kota Pekanbaru Dalam Meningkatkan Kedudukan Perempuan Tahun 2014). Jurnal Jom Fisip. Volume 4 No. 1

Undang-Undang No 23 Tahun 2014 Tentang Pemerintah Daerah 